\title{
An Important Strategy of Talent Management as Part of Business Development
}

\author{
Catur Supriyanto, Ria Marginingsih, Tri Elsa Susilawati, Phong Thanh Nguyen, K. Shankar
}

\begin{abstract}
To hire, retain, recruit and develop the most superior and talented employees in an organization the managers' commitment is known as talent management. For developing and retaining superior workforce all the work system and processes comprises as talent management. From the job market finding the skillful employee is a tough task. As the name implies talent management manage the talent of employees. For the development of the business it is a major concern to recruit the talented person. So he can move the business towards success.

Keywords: hire, recruit, talent management, business, development, format
\end{abstract}

\section{INTRODUCTION}

To retain the topmost skilled and talented employees in an organization the business strategy is consider as talent management. Like recognition of employees or involvement of employees the talent management is also a business strategy to attract the most talented people in the organization and it produce a competition with other employer. To motivate, attract, retain and develop high-performing employees it is the full scope of processes of HR.

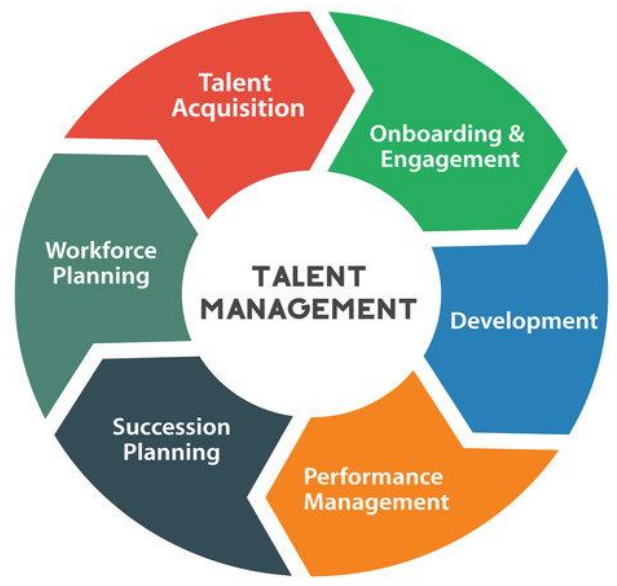

Figure 1: Talent Management

The definition of talent management has three elements as given below:

1. HR process full scope: Combination of many HR processes is integrated with each other in talent management. Activities of talent management are greater that other individual parts

Revised Version Manuscript Received on 16 September, 2019.

* Correspondence Author

Catur Supriyanto, Universitas Negeri Surabaya, Indonesia. E-mail

Ria Marginingsih, Universitas Islam 45, Indonesia.

Tri Elsa Susilawati, Universitas Islam 45, Indonesia.

Phong Thanh Nguyen*, Department of Project Management, Ho Chi Minh City Open University, Vietnam. E-mail: phong.nt@ou.edu.vn

K. Shankar, Department of Computer Applications, Alagappa University, India. E-mail: shankarcrypto@gmail.com catursupriyanto@unesa.ac.id

activities. It is necessary to capitalize the strategy of talent management on its full potential.

2. Retain, motivate, attract and develop: the work of talent management including on boarding of employees, hiring, retention and performance management. All these key areas are related to talent management.

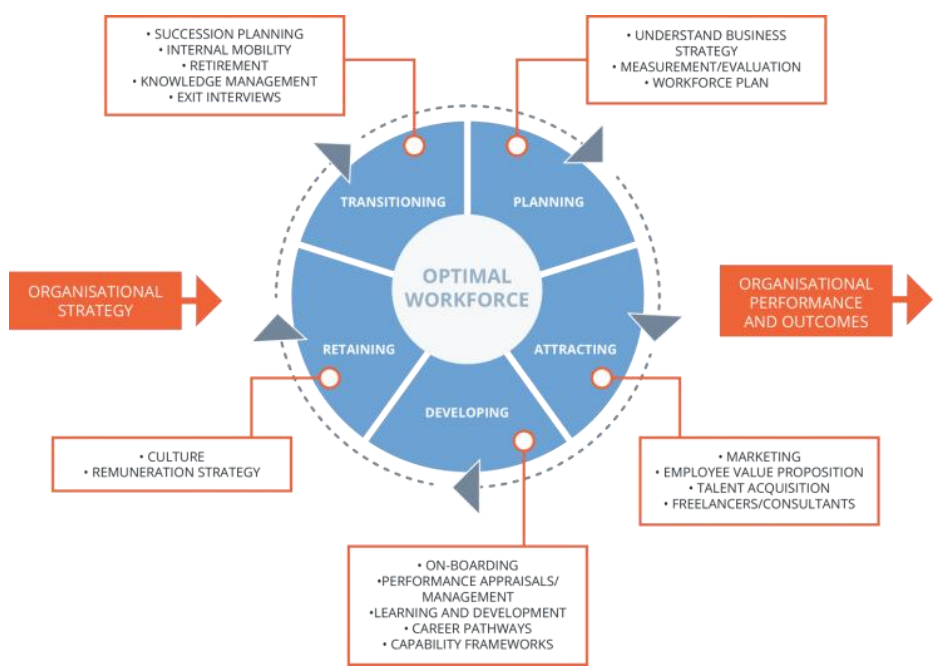

Figure 2: Talent Management Optimal Workforce

3. Employees high performance: Increasing the performance of overall business is the main objective of the talent management. To make the performance better the talent management engages, motivate and retain the employees. In this way talent management consider as an important factor. When process of talent management is done correctly the by integrated system of talent management practices using companies can make outperform their competition and sustainable competitive advantage which are difficult to imitate and copy.

\section{Processes of Talent Management System}

The phases of talent management are described as follows:

1. Goals Identification: For success of the complete process of talent management first stage is to define its goal. It should identify properly that what is the main aim of the organization and for achieving the goals what skills and qualifications characteristics are required.

2. Talent attraction: For an organization hire the best talented person is the main objective of the talent management. From the job market attract the best employees the organization make their efforts. 
3. Talent sourcing: In this stage, the ability the board work force searches for proper sources in the activity market or enterprises where the focused on individuals can be contracted or enrolled.

4. Employees Recruitment: This is the principal phase of employing the best capable individuals for the association. Talented and qualified individuals are welcome to join the association.

5. Employees Selection: This is where the goal of ability the executives turns into a reality. It is when genuinely capable individuals are enrolled or procured in different jobs.

6. Development and Training: At this stage, they chose enlisted people are furnished with fundamental preparing to make them beneficial and effective to progress in the direction of the objectives of the association.

7. Retention: The striking goal of ability the executives isn't just enlisting ability yet additionally guaranteeing their maintenance in the association. Variables whereupon the degree of consistency depends are alluring compensation bundle, work detail, wellbeing and security of the representatives, self-improvement of a worker, acknowledgment and culture of the association, and the fit between the activity and ability.

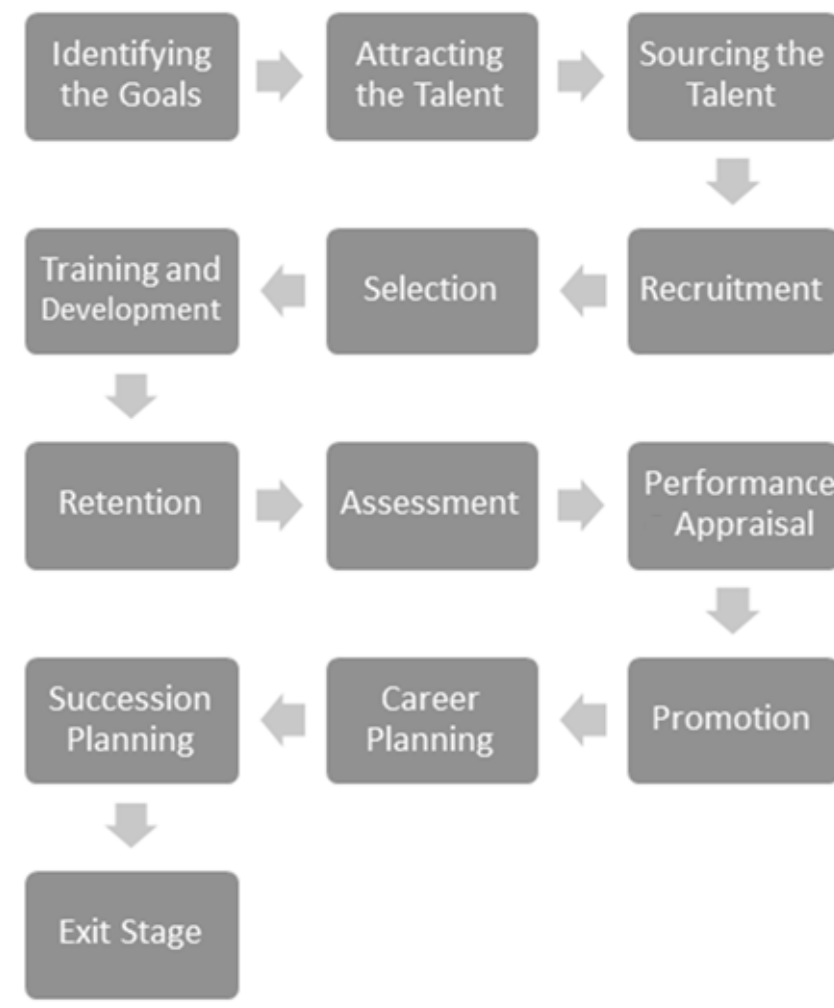

Figure 3: Process of Talent Management

8. Assessment: Periodical evaluation of representatives' aptitudes, capacities, enhancements and capabilities empower the association to know whether they are fit for continuation and advancement.

9. Appraisal of Performance: It is an estimation of the genuine presentation of the representatives in the activity. It empowers the association to learn if the individual can be stacked with additional duties.
10. Promotion of Employees: It alludes to work enhancement. It keeps the vitality level high of the representatives and they are motivated to keep on working for the association.

11. Planning of Career: If a representative is discovered befitting to deal with work weight and additional obligations well, the administration needs to design his/her profession so the person feels raised and compensated. Such acknowledgment and prizes move the representatives to stay with the association for quite a while.

12. Planning of Succession: This arrangement with the substitution of individuals inside the association. Workers who have given their best to the association and have been serving for long have the right to hold higher positions.

13. Exit stage: This is the last phase of ability the board procedure that finishes in the retirement of the workers and they are not any more a piece of the association.

\section{DIFFERENCE BETWEen TALENT MANAGEMENT AND HR}

For managing the people both HR and talent management is used but they are different at various points:

1. Implementation: Talent management is vital, frequently showing as an expansive, long haul plan intently connected with generally business objectives, while HR is progressively strategic, managing the everyday administration of individuals.

2. Structure: Hiring, preparing, and maintenance are unified in the HR division. In ability the executives, a large number of these obligations are part into their very own specialties or panels, spread over the organization. Thusly, the entire association is in charge of, and has a stake in, these exercises.

3. Responsibilities: HR is increasingly centered on organization. HR divisions manage pay, individual downtime, advantages, and grumblings. Ability the executives is independently centered on aiding and improving the top ability in the association. Think proficient improvement as opposed to following participation - both is imperative to an organization and both are about individuals, yet one is unquestionably increasingly administrative.

\section{Talent Management Pillars of Talent management}

Four main pillars on which the whole process of talent management depends are:

1. Management of performance: The ways in which it improves the performance of entire business and measure HR are included in this process.

2. Development and Learning: During the lifecycle of employee learning and ongoing training is included in this process.

3. Employee's Recruitment: The skilled and talented people attracted by the company's member to recruit in the company.

4. Retention: With the organization or company as long as possible keeping high performing talent is defined as retention. 


\section{Effect of Talent Management on Organizational} Performance

Right now, Human Resource Management (HRM) turns into a key pattern for business. Directors from science-based ventures give exceptional consideration to Talent Management, turning into a well known instrument in powerful association. As specific pieces of HRM can be bolstered by innovation, numerous ventures utilize uncommon programming, for example, HR Information Systems or HR Management Systems.

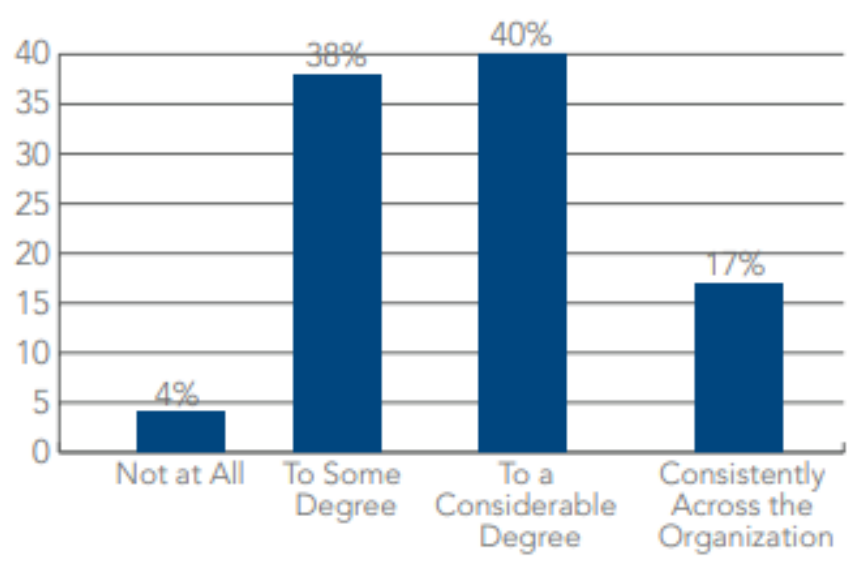

Figure 4: With business strategy degree of integration and alignment

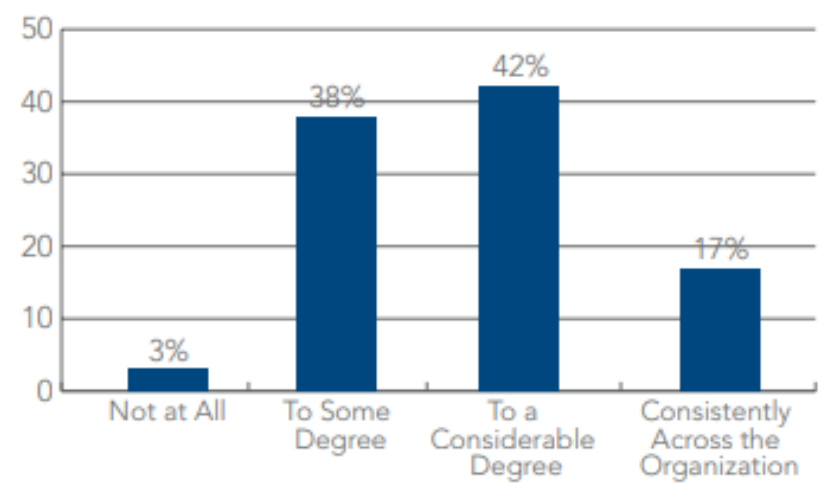

Figure 5: Degree of Identified Capabilities and critical roles

\section{Conclusion}

To retain the topmost skilled and talented employees in an organization the business strategy is consider as talent management. Like recognition of employees or involvement of employees the talent management is also a business strategy to attract the most talented people in the organization and it produce a competition with other employer.

\section{REFERENCES}

1. Suratkumari, M., \& B, J. (2012). Talent Management of south central railways. journal of commerce amd management thought , II (2).

2. Tucker, E., Kao, T., \& Verma, N. (2005). Next-generation talent management: Insights on how workforce trends are changing the face of talent management.

3. Berger, L. A. \& Berger, D. R. (Eds.). (2004). The Talent Management Handbook: Creating Organizational Excellence by Identifying, Developing and Promoting Your Best People. New York: McGraw-Hill.
4. Grigoryev, P. (2006) - Hiring by Competency Modelsll, the Journal for Quality \& Participation, Winter.

5. Lawler, E.E. (2005). From human resource management to organizational effectiveness. Human Resource Management. 44(2). $165-170$.

6. Chienwattanasook, K., Wattanapongphasuk, W., Prianto, A., \& Jermsittiparsert, K. 2019. "Corporate Entrepreneurship and Business Performance of Logistic Companies in Indonesia." Industria Engineering \& Management Systems 18 (3): 538-547.

7. Dawabsheh, M., Hussein, A., \& Jermsittiparsert, K. 2019. "The Triangular Relationship between TQM, Organizational Excellence and Organizational Performance: A Case of Arab American University Palestine." Management Science Letters 9 (6): 921-932.

8. Jermsittiparsert, K., Siam, M., Issa, M., Ahmed, U., \& Pahi, M. 2019. "Do Consumers Expect Companies to Be Socially Responsible? The Impact of Corporate Social Responsibility on Buying Behavior." Uncertain Supply Chain Management 7 (4): 741-752.

9. Syazali, M., Putra, F., Rinaldi, A., Utami, L., Widayanti, Umam, R., \& Jermsittiparsert, K. 2019. "Partial Correlation Analysis Using Multiple Linear Regression: Impact on Business Environment of Digital Marketing Interest in the Era of Industrial Revolution 4.0." Management Science Letters 9 (11): 1875-1886.

10. Sae-Lim, P. \& Jermsittiparsert, K. 2019. "Is the Fourth Industrial Revolution a Panacea? Risks toward the Fourth Industrial Revolution: Evidence in the Thai Economy." International Journal of Innovation, Creativity and Change 5 (2): 732-752.

11. Chatchawanchanchanakij, P., Arpornpisal, C., \& Jermsittiparsert, K. 2019. "The Role of Corporate Governance in Creating a Capable Supply Chain: A Case of Indonesian Tin Industry.” International Journal of Supply Chain Management 8 (3): 854-864.

12. Hartinah, S., Suharso, P., Umam, R., Syazali, M., Lestari, B., Roslina, R., \& Jermsittiparsert, K. 2020. "Teacher's Performance Management: The Role of Principal's Leadership, Work Environment and Motivation in Tegal City, Indonesia." Management Science Letters 10 (1): $235-246$.

13. Haseeb, M., Hussain, H., Slusarczyk, B., \& Jermsittiparsert, K. 2019. "Industry 4.0: A Solution towards Technology Challenges of Sustainable Business Performance.” Social Sciences 8 (5): 184.

14. Haseeb, M., Hussain, H., Kot, S., Androniceanu, A., \& Jermsittiparsert, K. 2019. "Role of Social and Technological Challenges in Achieving a Sustainable Competitive Advantage and Sustainable Business Performance.” Sustainability 11 (14): 3811.

15. Haseeb, M., Kot, S., Hussain, H., \& Jermsittiparsert, K. 2019. "Impact of Economic Growth, Environmental Pollution, and Energy Consumption on Health Expenditure and R and D Expenditure of ASEAN Countries." Energies 12 (19): 3598.

16. Huda, S., Tsani, I., Syazali, M., Umam, R., \& Jermsittiparsert, K. 2020. "The Management of Educational System Using Three Law Auguste Comte: A Case of Islamic Schools." Management Science Letters 10 (3) (In press), DOI: 10.5267/j.msl.2019.9.018.

17. Usak, M., Kubiatko, M., Shabbir, M., Dudnik, O., Jermsittiparsert, K., \& Rajabion, L. 2019. "Health Care Service Delivery Based on the Internet of Things: A Systematic and Comprehensive Study." International Journal of Communication Systems 32 (14): e4179.

18. Jermsittiparsert, K., Ambarita, D., Mihardjo, L., \& Ghani, E. 2019. "Risk-Return through Financial Ratios as Determinants of Stock Price: A Study from ASEAN Region.” Journal of Security and Sustainability Issues 9 (1): 199-210.

19. Thabhiranrak, T. \& Jermsittiparsert, K. 2019. "Towards Sustainable Functioning of Organization: Women Empowernment and Corporate Management Culture." Journal of Security and Sustainability Issues 9 (1): 321-332.

20. Chienwattanasook, K. \& Jermsittiparsert, K. 2019. "Impact of Entrepreneur Education on Entrepreneurial Self-Employment: A Case Study from Thailand." Polish Journal of Management Studies 19 (1): 106-116.

21. Jermsittiparsert, K., Sutduean, J., Sriyakul, T., \& Khumboon, R. 2019. "The Role of Customer Responsiveness in Improving the External Performance of an Agile Supply Chain." Polish Journal of Management Studies 19 (2): 206-217.

22. Jermsittiparsert, K., Sutduean, J., \& Sriyakul, T. 2019. "Effect of Service Innovation and Market Intelligence on Supply Chain Performance in Indonesian Fishing Industry." Industrial Engineering \& Management Systems 18 (3): 408-417. 
23. Jermsittiparsert, K., Namdej, P., \& Somjai, S. 2019. "Green Supply Chain Practices and Sustainable Performance: Moderating Role of Total Quality Management Practices in Electronic Industry of Thailand.” International Journal of Supply Chain Management 8 (3): 33-46.

24. Somjai, S. \& Jermsittiparsert, K. 2019. "The Trade-off between Cost and Environmental Performance in the Presence of Sustainable Supply Chain." International Journal of Supply Chain Management 8 (4): 237-247.

25. Jermsittiparsert, K. \& Sawasdee, A. 2012. "Formal Education for Non-Thai or Undocumented Person in Thailand amidst the Challenge of Nationalism and Transnationalism: A Case Study of Wat Sirimongkhol School, Samut Sakhon Province.” Kasetsart Journal Social Sciences 33 (2): 203-213.

26. Michaels, E., Handfield-Jones, H., \& Axelrod, B. (2001). The War for Talent. Boston: Harvard Business School Publishing.

27. Schweyer, A. (2004). Talent Management Systems: best practices in technology solutions for recruitment, retention and workforce planning. Canada: Tri-Graphic Printing.

28. OpasPiansoongnern et al., (2011), Talent Management in Thai cement companies: A study of strategies and factors influencing Employee Engagement, African Journal of Business Management,Vol 5(5), pp. 1578-1583

29. Julia Christensen Hughes and EvelinRog (2008), A strategy for improving employee recruitment, retention and engagement within hospitality Organization, International Journal of Contemporary Hospitality Management, Vol. 20 No.7, pp. 743-757.

30. Economist Intelligence Unit (2006) The CEO's role in talent management: How top executives from ten countries are nurturing the leaders of tomorrow. London, The Economist.

31. DeFillippi, R.J. and Arthur, M.B. (1994) "The boundaryless career: A competency-based perspective", Journal of Organizational Behaviour, 15, 307-24.

32. Huselid, M.A. and Becker, B.E. (2000) "Comment on 'Measurement error in research on human resources and firm performance: How much error is there and how does it influence effect size estimates' by Gherart, Wright, McMahon and Snell", Personnel Psychology, 53, 835-54.

33. George J.M. and Bettenhausen, K. (1990) "Understanding prosocial behaviour, sales performance, and turnover: A group-level analysis in a service context", Journal of Applied Psychology, 75 (6), 698-709. 